\title{
Discipline, resistance and self-improvement: Three phases in the growth of Fanny Price
}

\author{
Yingying DENG, Joan Qionglin TAN \\ College of Foreign Languages, Hunan University, Changsha, Hunan, China \\ Email address: \\ shuihendyy@163.com (Yingying Deng),joantan@hotmail.co.uk (Joan Qionglin Tan)
}

To cite this article:

Yingying DENG, Joan Qionglin TAN. Discipline, Resistance and Self-Improvement: Three Phases in the Growth of Fanny Price. International Journal of Literature and Arts. Vol. 2, No. 4, 2014, pp. 123-129. doi: 10.11648/j.ijla.20140204.16

\begin{abstract}
Fanny Price is a remarkable heroine of Mansfield Park written by Jane Austen. Based on Michel Foucault's power theory and the related theories about subjectivity construction, this paper aims at analyzing how Fanny tries to adopt, resist and make the most of the underlying various power mechanisms in a patriarchal society and how she achieves her own self-education and self-improvement. It contends that through three phases of discipline, resistance and self-improvement, Fanny successfully transforms herself from an inferior "outsider" into a noble and elegant lady welcomed by the middle class in British society in the early $19^{\text {th }}$ century.
\end{abstract}

Keywords: Fanny Price, Mansfield Park, Michel Foucault, Disciplinary Power, Technologies of the Self

\section{Introduction}

Jane Austen (1775-1817), one of the most influential female writers in the British literature, mainly explored women's marriage and life in the British countryside in the late $18^{\text {th }}$ century and the early $19^{\text {th }}$ century and truly reproduced love stories between ladies and gentlemen in the Victorian era. Austen created six novels in her lifetime, among which Pride and Prejudice (1812) is most well-known, while Mansfield Park (1814) is fairly controversial. Critics have mixed reviews on Mansfield Park; some appreciate the orthodox morality exhibited in the heroine Fanny Price and the skillful writing tactics of this novel; while others hold that Fanny Price is the most dull, passive or even conservative one in all Austen's heroines. Traditional interpretation of the protagonist Fanny Price focuses on interpreting her personalities. For example, the critic Avrom Fleishman suggests that "Fanny is presented not as a paragon of virtue, but as a weak woman with self-defensive and self-aggrandizing impulses" (1967:46). And Nina Auerbach compares Fanny to some famous monsters appeared in some literary works, like monsters Grendel and Dr Frankenstein (1983:208-223). In the same year, Margaret Kirkham justifies Fanny's position in Jane Austen, Feminism and Fiction by praising her as an example of "the typical conduct-book heroine" in Austen's novels. The critic Susan C. Greenfield focuses her analysis on Fanny's ethical principles and virtues, especially the interior virtues and authority (1994: 306-322); while Anna Despotopoulou interprets Fanny and her personalities from the perspective of "differentiating feminine power" (2004:569-583). Few critics try to analyze the underlying various power mechanisms in a patriarchal society which contribute to her personalities. Though Mary Chan tentatively proposes that Fanny suffers from the paradoxical gaze in Mansfield Park, she fails to present a complete picture as to how Fanny adopts, resists and makes the most of the power mechanisms and finally enjoys a happy ending. Hence, this paper attempts to reinterpret the heroine Fanny Price from the perspective of Michel Foucault's power theory and the related theories about subjectivity construction. It contends that Fanny's growth from an inferior "outsider" into a noble and elegant lady has gone through three phases, that is, discipline, resistance and self-improvement. Also, this paper articulates that Fanny is not a submissive and conservative heroine as reviewed within traditional interpretations; on the contrary, she is a heroine who knows how to make the most of the disciplinary power for her self-education and self-improvement. In this respect, she is a representative of new women who is conservative, but open and brave enough to pursue her own happiness and social status in a disciplinary society.

Michel Foucault, one of the most celebrated thinkers in the $20^{\text {th }}$ century, is also a distinguished French philosopher and historian. He produced many thought-provoking works, 
such as The Archaeology of Knowledge (L'Archéologie du Savoir, 1969), Discipline and Punish: The Birth of the Prison (Surveiller et punir: naissance de la prison, 1975) and The History of Sexuality (Histoire de la sexualité, 1976-1984), which exerted great influence on the then humanities and social sciences. In particular, the power-knowledge (pouvoir-saviour) theory proposed by Foucault has challenged many traditional interpretations of power in the Western societies. Foucault holds "that traditional conception of power is defined as prohibitive and negative and is used to prohibit people from doing something", but in fact, "power is much more complicated than this"(Foucault, 1980:147). As the critic Mo Weiming points out, "Power is not an institution or a mechanism which is used to ensure the submission and obedience of citizens in a particular nation; neither is it a licit way to conquer compared with violence; nor is it a general ruling system exerted by one constituent or group on another, the effect of which is permeated into the whole social body by continuous derivation." (1996:264). Instead, power is a kind of complicated, mobile and unstable relation. Meanwhile, Foucault analyzes power from the perspective of deconstructionism and concludes that the essence of power is "decentered", "fragmented", "discontinuous" and "diverse", which is quite subversive and revolutionary.

Foucault redefines power from the micro level and first proposes the notion of disciplinary power in Discipline and Punish: The Birth of the Prison. Quite different from the previous punishments, Foucault points out that the punishment in the modern society is not a physical one any more; instead, it is "replaced by a punishment that acts in depth on the heart, the thoughts, the will, the inclinations" (Foucault, 1991:16). Though body is not the target of punishment, it is still the object of imprisonment. The disciplinary power in modern society is a kind of technical strategy which aims at controlling and disciplining individuals and groups both in body and soul and complying them to social norms and requirements by a series of instruments. Such instruments include "hierarchical observation, normalizing judgement and their combination in a procedure that is specific to it, the examination" (Foucault, 1991: 170). Among them, the most typical is Foucault's employment of panopticon put forward by British philosopher Jeremy Bentham to illustrate how the disciplinary power works in the whole society. The disciplinary power consists of external and internal disciplinary power. The external disciplinary power mainly refers to the political-economic power and ideological power, which is termed as the construction of individuals by the external controlling technologies, namely, individuals in this sense are jointly constructed by sociality and historicity. The internal disciplinary power refers to the self-disciplinary power which is defined as the construction of individuals by technologies of the self, and individuals in this sense is constructed by self-ethics. The heroine Fanny Price goes through a transformation from resistance to self-improvement under the joint function of these two disciplinary powers.

\section{Fanny's Resistance to External Disciplinary Power}

Foucault adopts panopticon to vividly elaborate how the disciplinary power works in the whole society and the operating principle can be summarized as follows, at the periphery, an annular building; at the center, a tower; this tower is pierced with wide windows that open onto the inner side of the ring. The supervisor in the central tower can supervise every prisoner in every single cell, observe their behaviors and pass the normalizing judgement to those prisoners who fail to fulfill the requirements. However, prisoners have no sight of the supervisor and even have no idea when they are supervised and when they are not (Foucault, 1991: 200).

Gradually, the effect of panopticon is that the prisoners will internalize the external supervision and achieve the goal of self-supervision and discipline themselves to comply with the social standards and requirements. This paper contends that Mansfield Park described in Austen's novel can be regarded as one kind of Bentham's panopticon, as it corresponds to one of Foucault's disciplinary technologies, namely, space allocation and space orientation. The Park has its own disciplinary and punitive rules, which is concretized by Sir Thomas Bertram's country gentlemen's ethics and "the frugal and practical ethics" and "more rational and less implied teachings" beheld by the emerging bourgeoisie (Lane, 2005: 114). What is more, Foucault specifically mentioned in The Eye of Power that "one doesn't have here a power which is wholly in the hands of one person who can exercise it alone and totally over the others. It is a machine in which everyone is caught, those who exercise power just as much as those over whom it is exercised" (Foucault, 1980: 156). Therefore, everyone in the Park, high or low, shall be submitted to these rules. Once violated, no one can escape the due punishment, as it is evidenced by two examples: the expulsion of Maria Bertram and Henry Crawford after their elopement; the exclusion of Mary Crawford because of her philistine, self-centeredness and contempt of social ethics.

\subsection{Fanny's Resistance to Political-Economic Power}

Mansfield Park is an epitome of the patriarchal society, in which social status matters a lot. Fanny sojourns in the Park as a charity ward and Sir Thomas Bertram is her benefactor which lays the foundation of Fanny's inferior position in the Park at its source. Sir Thomas Bertram is the center of the whole family and dominant in almost all family affairs, from Antiguan plantation to Fanny's horse-riding and the heating in the East Room. Sir Thomas Bertram has the absolute authority over everyone and everything in the Park and is rather hard on his own children, which can be illustrated by everybody's reaction to his departure to Antigua:

Their father was no object of love to them; he had never seemed the friend of their pleasures, and his absence was 
unhappily most welcome. They were relieved by it from all restraint; and without aiming at one gratification that would probably have been forbidden by Sir Thomas, they felt themselves immediately at their own disposal, and to have every indulgence within their reach. Fanny's relief, and her consciousness of it, were quite equal to her cousins'; (Austen, 2009: 737)

The temporary absence of Sir Thomas frees Fanny from his constant surveillance and censorship so that Fanny feels relieved. This can well evidence that Sir Thomas acts as an invisible supervisor of Fanny's actions and speeches and disciplines her with his inherent ethical conduct standards. The authoritarian tone permeates almost the whole novel, as it can be seen from Fanny's coming-out ball held by Sir Thomas. Before the ball ends, Sir Thomas advises Fanny to take a rest. Superficially, Sir Thomas shows his concern to his little niece. Substantially, this concern carries a ring of authority and coerciveness, as it is depicted in the novel, "'Advise' was his word, but it was the advice of absolute power..." (Austen, 2009: 871). Another typical case in point is Sir Thomas's fury at Fanny's sheer refusal to the playboy Henry's proposal regardless of his repeated persuasion. He banishes Fanny from the Park and sends her back to that poor family in Portsmouth on the ground of home visits, for he thinks that Fanny's refusal is contempt of his absolute authority. Finally, Fanny is permitted to go back to the Park only after she realizes her mistakes and a series of incidents threatening the stability and ethics of the Park, such as the elopement of Maria and Henry; the severe illness of Tom and Mary's instigation of Edmund to take place of Tom's rank of nobility. The reason why Sir Thomas wants Fanny back to the Park lies in that Fanny's inherent virtues and absolute submission to his authority and ethics that he hopes set up a model for others in the Park, stable the order and rescue people from losing the basic morality. All of these fully exhibit how Foucault's series of disciplinary instruments work in the Park: Fanny's behaviors and speeches are closely monitored to ensure that she is submissive to the authority and ethics in the Park; once violated, she will be punished by Sir Thomas's normalizing judgement - "exile" so as to discipline her to be qualified spokeswoman of morality in the Park.

Fanny's great aunt Mrs. Norris is another figure who exerts great influence on Fanny's life. Mrs. Norris voluntarily acts as a housekeeper in the Park and is keen on meddling and bossing around, but refuses to help others. From the first time she meets Fanny, "Mrs. Norris had been talking to her the whole way from Northampton of her wonderful good fortune, and the extraordinary degree of gratitude and good behavior which it ought to produce..." (Austen, 2009: 726-727), which is an employment of social ethics restraint mechanisms to remind Fanny of not forgetting her inferior identity and social status. She supervises Fanny's behaviors and speeches from time to time. On the one hand, she never considers Fanny as one member of the Park, so whenever there are group outings, she autonomously degrades Fanny and discourages her from going. So, when Mrs. Rushworth invites the Bertrams to visit Sotherton, Mrs. Norris self-asserts that Fanny should stay behind and accompany Mrs. Bertram. On the other hand, once Fanny fails to subsidize her own life in the Park by doing some needlework, she will be bitterly criticized and satirized by Mrs. Norris without considering the reasons. For example, on one occasion Fanny lies on the sofa due to her illness, Mrs. Norris criticizes her and thinks that "it is shocking trick for a young person to be always lolling upon a sofa" (Austen, 2009: 759). It is the incessant admonition and criticism that teaches Fanny the rules of survival in the Park, which is the exact effect the political-economic disciplinary power intends to yield and fulfill.

Surely, apart from Sir Thomas and Mrs. Norris, Fanny exposes herself to the visible or invisible surveillance of other people in the Park. This is what Foucault proposed: "Power relations are open text; the exercise of power relations comes from everywhere and is not confined to specified domains" (Mo Weiming, 1996: 265) or specified objects. Public opinions are expressions of the disciplinary power. The first moment Fanny enters into the Park, she feels the ubiquitous surveillance: “...She was disheartened by Lady Bertram's silence, awed by Sir Thomas's grave looks, and quite overcome by Mrs. Norris's admonitions. Her elder cousins mortified her by reflections on her size, and abashed her by noticing her shyness; Miss Lee wondered at her ignorance, and the maid-servants sneered at her clothes..." (Austen, 2009: 727). The whole Park is a panoptican in which Fanny lives as a "prisoner" and unconditionally receives everybody's hierarchical surveillance and censorship from Sir Thomas to her cousins or even servants. In the following eight years, even though Fanny has internalized the survival and game rules in the Park, she cannot slacken off and has to live cautiously and prudently in everybody's "gaze".

As an "outsider" and "intruder", Fanny's reaction to this surveillance has changed from original fear and shyness to decent living therewith after a period of adoption. Superficially, Fanny shows her absolute submission to Sir Thomas's authority and lives by his codes of conduct and ethics. "...You (Fanny) seemed almost as fearful of notice and praise as other women were of neglect"(Austen, 2009: 826). However, Fanny's ostentatious cowardice, obedience and silence, to some degree, is her resistance to the political-economic disciplinary power, as she does not want to ingratiate herself with the male in the patriarchal society with her inherent beauty and virtues. In order not to be interfered by the outside disturbances, she tactfully creates her own space by making use of the East Room (a disused study room) in a limited space allocation and space orientation, in which she can express her ideas freely, soothe her wounded feelings and do whatever she wants to do without worrying about others' surveillance and punishment. The critic Anna Despotopoulou comments that "From her early childhood, she builds a unique feminine space for herself which remains uncontaminated and uninterrupted by male involvement" (2004: 570). The East Room where 
Fanny successfully transforms herself from an inferior "outsider" into a noble and elegant lady fully manifests the awakening of her feminine consciousness and struggling against the suffocative disciplinary power, which contributes to Fanny's being beneficiary and master of this power.

\subsection{Fanny's Resistance to Ideological Power}

Edmund Bertram is the only one of all Bertrams who is ready to associate with Fanny from the beginning and he can be regarded as an enlightened mentor who helps Fanny acquaint herself with her life in the Park. When Fanny is fearful and anxious about the life, it is Edmund who "directs her thoughts and fixes her principles", "assists the improvement of her mind and extends its pleasures", "encourages her taste and correct her judgement"(Austen, 2009: 934, 731) and stimulate her interests to learn and read. Edmund's identity is special for he is trained to be a potential clergyman by Sir Thomas, so in his association with Fanny, his inherent ideas and thoughts will infiltrate into Fanny's mind unconsciously. A good case in point is the discussion of the clergyman as a job among Mary, Edmund and Fanny. Mary tries to dissuade Edmund from taking orders and becoming a clergyman, because she thinks a clergyman is nothing and cannot gain distinction, arguing that the influence and importance of the clergyman and his sermons are small or even little. But Edmund and Fanny highly disagree with her ideas and retort that what Mary describes may occur in the big cities like London, but the situation is quite different in the nation at large, especially in the small countryside. Here, "A clergyman has the charge of all that is of the first importance to mankind, individually or collectively considered, temporally and eternally, which has the guardianship of religion and morals, and consequently of the manners which result from their influence" (Austen, 2009: 770). And the influence of a clergyman does not depend on the high or low position; instead, it lies in whether a clergyman fulfills his duties or not in governing the conduct and fashioning the manners of a large congregation. From this discussion, it is obvious to conclude that Edmund's influence and inculcation on Fanny about his opinions of clergyman and religion are great and deep-rooted in the process of helping Fanny adapt to the life in the Park, which is Edmund's way of exercising the ideological disciplinary power on Fanny. He successfully disciplines Fanny to identify with him in religion and morals and become another spokeswoman and advocate of his opinion by constant exposure and discussion. Fanny's religious cognition and recognition gained from this invisible disciplinary power is precisely what the then society advocated, which foreshadows her happy ending.

Sir Thomas's exercise of the ideological disciplinary power on Fanny is achieved by appreciation and admonition. Sir Thomas greatly appreciates Fanny's sheer refusal to play a role in Lovers' Vows and deems that she well maintains the ethical tradition of the Park after he returned from Antigua. Sir Thomas's another way to discipline Fanny is to warn her by admonishing and punishing other people. After Mrs.
Rushworth and Mr. Crawford's elopement was exposed to the public, Mrs. Norris suggests that Maria should be embraced again by her family members, but Sir Thomas refuses it flatly, "...he would not, by a vain attempt to restore what never could be restored, by affording his sanction to vice, or in seeking to lessen its disgrace..." (Austen, 2009: 971). On the contrary, he banishes Maria and Mrs. Norris who spoilt Maria heavily from the Park. Sir Thomas successfully embeds and reinforces his ethics and code of conduct into Fanny's cognition by appreciation and encouragement, which is the manifestation of reward principle in the modern prison institution. In the meanwhile, he explicitly admonishes Fanny that any misconduct which goes against the moralities of single or married ladies will be heavily condemned and punished by disavowing the eloping Maria. All of these are targeted at submitting Fanny to his ideological control, which vividly illustrates Foucault's new idea of disciplinary power in the modern society, that is, this kind of disciplinary power is not confined to the physical punishment, but more about the control and discipline of thoughts and cognition.

Fanny's cleverness lies in her recognition that though her cognition and ethics are disciplined by Edmund and Sir Thomas, she can well internalize it and act it on others. Fanny's resistance fully elaborates the mutuality of power: on the one hand, everyone can exercise power freely and becomes the acting subjects over others; on the other hand, everyone can become the controlled objects of other people. This resistance is achieved by Fanny's "feminine gaze". Gaze is a relationship between seeing and being seen; and it is also a process of wielding power on others and being controlled by others. We can obviously read from the novel as to how Fanny expresses her silent but still forceful rebellion by her unique "feminine gaze". Since ancient times, female has been humiliated by male sexual and erotic gaze and oppressed by male authority. However, Fanny once broke off male humiliating and sexual gaze through her unique gaze, which, to some degree, has challenged the patriarchy ideology (Gamman, 1989: 15-16). Put Henry's moral quality aside, Fanny shows her due appreciation of this playboy, who she once observed Henry's reading hours with her appreciating gaze. The critic Anna Despotopoulou remarks that "Fanny views Crawford as he habitually views her - as an art object" on the artwork market (2004: 581), which evidences that Fanny successfully counterattacks male sexual gaze with female judging and sexual gaze. Besides, Edmund feels confused about himself, his notion of ethics and love, and is even on the verge of going wrong; especially after recognizing Mary's self-centeredness, he falls into despair. Fanny enlightens him by face-to-face chats over stroll after dinner and encourages him to get out of the confusion and finally make the right choice with her determined gaze. It is Fanny who helps Edmund “....had so well talked his mind into submission as to be very tolerably cheerful again" (Austen, 2009: 970). Fanny's counteraction precisely subverts the patriarchal discourse and the traditional idea that only the powerful male gaze can control 
the female, which is the convincing evidence of female gaze's powerful reaction and female's interior authority.

\section{Fanny's Self-Improvement under Internal Disciplinary Power}

Foucault devoted himself to studying the evolution of the subjects in his several books, such as Madness and Civilization (Histoire de la folie à l'âge classique - Folie et deraison, 1961), The Order of Things (Les Mots et les choses: une archéologie des sciences humaines, 1966), Discipline and Punish: The Birth of the Prison and The History of Sexuality, in which he switches his notions from the earlier "Knowledge Subject" to "Power Subject", and then to the later "Ethical Subject". The construction of the latter two Subjects is fulfilled by technologies of domination and technologies of the self. Foucault's definition of "technologies of the self" is the kind of technologies "which permit individuals to effect by their own means or with the help of others a certain number of operations on their own bodies and souls, thoughts, conduct, and way of being, so as to transform themselves in order to attain a certain state of happiness, purity, wisdom, perfection, or immortality" (Foucault, 1988: 17). After perusing the Stoic works in the ancient Greek and Roman times and the doctrinal practices of the early Christianity, Foucault concludes four technologies of self: "letters to friends and disclosure of self; examination of self and conscience, including a review of what was done, of what should have been done, and comparison of the two; askesis and the interpretation of dreams" (Foucault, 1988: 17). This paper contends that these four technologies can be categorized into two self-improving technologies: one is internal self-improving technologies which indicates that individuals effect themselves by their own means, including examination of self and conscience, askesis and the interpretation of dreams; the other is external self-improving technologies which individuals effect themselves with the help of others, including letters to friends and disclosure of self. These two technologies are closely related to the function of internal self-disciplinary power, which fully exhibits in Fanny's transformation from an early ignorant intruder into a graceful lady within the Park.

Due to the panoptican-like surroundings of the Park and the ubiquitous gazes of various people, Fanny's life is characterized by constant examinations of self and conscience and askesis. However, askesis here does not only refer to Fanny's repression of sexual desires as some critics propose, it also refers to the repression of political-economic and ideological desires. Unconsciously, she interiorizes the disciplinary effects of political-economic power, religion and ethics into self-surveillance and self-examination, which changes her opinions of social politics, economy, religion and ethics. This is what Foucault points out in his interview The Eye of Power: "There is no need for arms, physical violence, material constraints. Just a gaze. An inspecting gaze, a gaze which each individual under its weight will end by interiorizing to the point that he is his own overseer, each individual thus exercising this surveillance over, and against, himself'(Foucault, 1980: 155). Fanny's self-surveillance fully manifests in her sheer refusal to play the role of a cottager's wife in Lovers' Vows. What is more, even when others in the Park are complacent about being able to play, she still strongly opposes to the playing of Lovers' Vows in the Park, because she knows it well that the play and their behaviors violate the social ethics and "subvert the codes that govern ladylike behavior" (Knox-Shaw, 1996: 216). And their behaviors will damage single ladies' reputation and be severely condemned by Sir Thomas. Therefore, though Fanny greatly appreciates Edmund's any interests and hobbies before, she feels deeply disappointed about Edmund's decision to play the role of Anghat. In her sub-consciousness, her self-surveillance has overcome the deep-rooted admiration for her cousin. Any behavior or recognition which goes against the then social ethics and moralities, especially challenges Sir Thomas's authorities, will be vigorously rejected by Fanny. On hearing of the elopement of Mrs. Rushworth and Mr. Crawford, her reaction is strong enough to deem that "it was too horrible a confusion of guilt, too gross a complication of evil, for human nature, not in a state of utter barbarism, to be capable of!'(Austen, 2009: 958), which is a perfect embodiment of Fanny's voluntary self-examination and self-askesis. Consequently, whenever and wherever she is, Fanny is always cautious about her words and actions and fulfills her self-examination and self-surveillance, which is the ultimate aim that Foucault's disciplinary power attempts to achieve. Put it another way, the disciplined individuals will voluntarily abide by the social law and rules under the weight of long-term supervision and potential penalties, which encourage them to fashion themselves into a self-disciplined and self-cautious social members.

Another way to achieve self-disciplinary power is to gradually change oneself with the help of others. Foucault proposes that writing letters to friends and disclosing oneself is one form to achieve self-improvement. However, this form is far beyond writing letters; and any other communication forms which can achieve the aim of effecting individuals on their own bodies and souls, thoughts, conduct, and ways of being can be regarded as functional forms of self-disciplinary power. The first person to help Fanny improve herself in the Park is her mentor Edmund, her brother William-substitute and "the sympathetic, attentive father-teacher" (Murray, 1997: 23) in the long absence of Father. Before Fanny becomes accustomed to the life in the Park, it is Edmund who helps her to alleviate loneliness and fears by giving her brotherly care and nearly fatherly love. When Fanny first attends the coming-out ball, she realizes the fact that her beauty is admired and gazed by various suitors, including Sir Thomas, which upsets her a lot Still, it is Edmund who encourages Fanny to frankly accept admiration and attention. Therefore, it is natural for her to consider Edmund as an indispensible person in her life. 
Apart from Edmund, other people, such as her cousins Maria and Julia and her friend Mary Crawford, have also contributed to her growth into an elegant lady, even though their contributions are unintentional. When Fanny first comes to the Park, her cousins exhibit their versatile talents and geographical and historical knowledge before her. Their versatility and extensive knowledge are in stark contrast with Fanny's utter ignorance, which stimulates Fanny to pay more attention to the cultivation of talents and the growth of knowledge. Mary's help to Fanny lies more in stimulation and inspiration. Mary, an aristocratic lady coming from London who is cheerful, sincere and versatile, is the first lady Edmund admires. To Fanny who loves Edmund secretly, she is an appropriate woman for Fanny to learn from. Fanny tries her utmost to learn Mary's manners and behaviors and her talents, so as to achieve her self-improvement. In the meanwhile, she learns lessons from other people's mistakes and reflects on her own behaviors. For example, from Maria and Henry's indecent behaviors in Sotherton and in the rehearsal of Lovers' Vows, and Mary's bold and reckless speeches, she gets to know what reservedness and fidelity really mean and what ethical codes can not be transgressed and despised. In his later years, Foucault emphasizes that "individuals should emancipate themselves from generalized and normative restraints and restore their free, ethical and aesthetic existence" (Yang Dachun, 2002:173). Although Fanny completes her Subject Construction under the disciplinary power weight of the social prevailing and normative ethical codes, she never loses herself and subjective freedom and falls prey to be a passive Subject. On the contrary, she retains her own feminine consciousness and independence and pursues a free, ethical and aesthetic lifestyle and attitude, which is Fanny's self-determined "mode of existence or lifestyle". This kind of existence is, to some degree, "aesthetic and ethical choice", contrasting to ethic modes which are closely related to mandatory principles (Deleuze, 2012:108). This recognition Fanny gains is the most important and crucial step in her growth into the future mistress in the Mansfield Park and the essential phase in her successful self-construction.

\section{Conclusion}

Although the whole Mansfield Park is just like the panoptican depicted by Jeremy Bentham and Fanny is exposed to the complicated and disciplinary surveillance and examination from time to time, she artfully and flexibly converts the various disciplinary powers, whether political-economic power, ideological power or self-supervision and self-examination, into the impetus to self-improve and self-mature. Doubtlessly, Fanny finally achieves her dream of becoming a noble and elegant lady welcomed by the middle class in the early $19^{\text {th }}$ century British society. She transforms other people in the Park with her unique scrutinizing gaze, makes them realize their mistakes and helps them achieve self-improvement and self-realization. As the critic Mary Chan comments, "Fanny becomes the model prisoner under the rule of the panoptic gaze, and in the process, she learns to become a better observer than anyone else. Finally, Fanny exhibits an alternative gaze, one based on spectatorship, which contravenes and subverts the panoptic gaze that appears so powerful in the text" (Chan, 2002: 39). Fanny restores the disordered Mansfield Park life into a new order with her inherent virtues and rigorous ethical practices, which wins universal recognition and approval from Sir Thomas and other people in the Park. Consequently, she ends up with a happy marriage life with her most admired cousin Edmund. Fanny's happy ending indicates that though the disciplinary power is pervasive and ubiquitous in the modern society, it is not fearful and it is, to some extent, an important tool to justify the existence of human beings and their life, namely, what human beings mean to be human. Individuals in the disciplinary society can not be passively controlled by these powers, instead, they should take advantage of them to self-improve and self-educate and finally achieve their own fulfillment and happy endings.

\section{References}

[1] A. Fleishman, A Reading of Mansfield Park: An Essay in Critical Synthesis, Baltimore and London: Johns Hopkins University Press, 1967.

[2] N. Auerbach, "Jane Austen's dangerous charm-feeling as one ought about Fanny Price", In Jane Austen: New Perspectives, Janet Todd, Eds. New York and London: Holmes and Meier, 1983, pp.208-223.

[3] M. Kirkham, Jane Austen, Feminism and Fiction, Brighton, UK: Harvester Press, 1983; New York: Methuen, 1986.

[4] S. C. Greenfield, "Fanny's misreading and the misreading of Fanny: women, literature, and interiority in Mansfield Park", Texas Studies in Literature and Language, 1994, vol. 36. 3, pp.306-322.

[5] A. Despotopoulou, "Fanny's gaze and the construction of feminine space in Mansfield Park," The Modern Language Review, 2004, vol. 99. 3, pp. 569-583.

[6] M. Chan, Vision and Visibility: Power and the Observer in Jane Austen's Novels. Hamilton: McMaster University, 2002, unpublished.

[7] Minan Wang, "Power," In Key Words of Western Literary Theory, Yifan Zhao, Zhongzai Zhang, and De'en Li, Eds. Beijing: Foreign Language Teaching and Research Press, 2006, pp. 442-456.

[8] Minan Wang, "Foucault," Foreign Literature, 2010, vol 3, pp. 83-93.

[9] M. Foucault, "The eye of power," In Power/Knowledge: Selected Interview and Other Writings 1972-1974, Colin Gordon, Eds. Hetfordshire: Harvester Press Limited, 1980, pp. 146-165.

[10] Weiming Mo, The Destiny of Subject--A Study of Foucault's Philosophy (Zhuti de Mingyun--Fuke Zhexue Sixiang Yanjiu). Shanghai: the Joint Publishing Company Ltd, 1996. 
[11] Binghui Chen, "Foucault's outlook on power (Fuke de quanli guan)," Journal of Xiamen University (Social Sciences), 2002, vol. 4, pp. 84-90.

[12] M. Foucault, Discipline and Punish: The Birth of a Prison, Trans. A. Sheridan, London: Penguin Books, 1991.

[13] M. Lane, Jane Austen's World: The Life and Times of England's Most Popular Novelist, London: Carlton Books Limited, 2005.

[14] J. Austen, Mansfield Park, In Selected Works of Jane Austen, Shanghai: World Publishing Corporation, 1814.

[15] L. Gamman, "Watching the detectives: the enigma of the female gaze," In The Female Gaze: Women as Viewers of Popular Culture, L. Gamman and M. Marshment, Eds. Seattle: Real Comet Press, 1989, pp.15-16.

[16] L.H.Martin, Et al. Technologies of the Self: A Seminar with Michel Foucault, Amherst: University of Massachusetts Press, 1988.
[17] M. Foucault, The Use of Pleasure, In The History of Sexuality Volume 2, Trans. Robert Hurley, New York: Pantheon Books, 1985.

[18] M. Foucault, The Care of the Self, In The History of Sexuality Volume 3, Trans. Robert Hurley, New York: Pantheon Books, 1986.

[19] P. Knox-Shaw, "Fanny Price refuses to kowtow," The Review of English Studies, New Series, 1996, vol. 47. 186, pp. 212-217.

[20] D. Murray, "Spectatorship in Mansfield Park: looking and overlooking," Nineteenth-Century Literature, 1997, vol. 52. 1, pp. 1-26.

[21] Dachun Yang, "A new subject--a discussion of Foucault's later thoughts (Bieyi zhong zhuti-lun Fuke wanqi sixiang de zhiyi)," Zhejiang Social Sciences, 2002, vol. 3, pp. 169-173.

[22] G. Deleuze, Pourparlers (Zhexue yu quanli de tanpan), Trans. Liu Hanquan, Nanjing: Yilin Press, 2012. 